\section{Using additive indices and principal components to select sexual genitors and hybrids of Urochloa decumbens}

\author{
Filipe Inácio Matias ${ }^{1 *}$, Cacilda Borges do Valle², Beatriz Tomé \\ Gouveia $^{3}$, Gustavo Vitti Moro ${ }^{4}$ and Sanzio Carvalho Lima \\ Barrios $^{2}$
}

\begin{abstract}
The selection of sexual genitors in Urochloa decumbens breeding is dependent upon the performance of their progeny for several traits simultaneously. Thus, our objectives were to (i) compare the efficiency of indices to select genitors of $U$. decumbens, (ii) evaluate the genetic gains obtained through selection intensities, and (iii) evaluate the multivariate pattern of progenies through principal components analysis (PCA). For this purpose, 1415 hybrids from 75 progenies of full siblings were evaluated at Embrapa Beef Cattle (Brazil) using seven cuts for dry matter production, regrowth, protein, fiber, lignin, and percentage digestibility. Statistical analyses were performed using mixed models and PCA. The direct selection for dry matter production provided a $37.51 \%$ genetic gain. Agronomic traits using indices provided greater gains. Genitors selected using PCA Biplot were similar to selections using indices. Indices and PCA were proven to be an excellent tool to select multi-traits in $U$. decumbens.
\end{abstract}

Keywords: Brachiaria decumbens, genetic gain, recurrent selection, tropical forage.

\section{INTRODUCTION}

Urochloa decumbens is a perennial savanna grass native to Africa and widely grown in pastures to feed cattle on tropical livestock farms (Euclides et al. 2016). The success of this species is because of its high biomass production in warm and dry environments, regrowth capacity, and tolerance to acidic soils (Jank et al. 2014). Despite the importance of this species to tropical regions, there is only one cultivar registered in the Brazilian National Register of Cultivars (RNC 2020), U. decumbens Basilisk (Jank et al. 2014). It is a segmental allotetraploid and aposporous apomictic (Worthington et al. 2016). Apomixis is a reproduction system where the plant propagates clonally by seeds, and thus, prevents hybridization between different individuals (Miles 2007, Jank et al. 2011). However, in 2009, a sexual diploid accession of $U$. decumbens was artificially tetraploidized using colchicine (Simioni and Valle 2009) providing the possibility to start intraspecific hybridization with the apomictic $U$. decumbens Basilisk as the pollen donor.

With the availability of sexual tetraploid plants of $U$. decumbens, the recurrent selection breeding scheme was adapted to develop new cultivars (Barrios et al. 2013). Miles (2007) and Worthington and Miles (2015) also reported
Crop Breeding and Applied Biotechnology 20(2): e28082022, 2020 Brazilian Society of Plant Breeding. Printed in Brazil http://dx.doi.org/10.1590/198470332020v20n2a18

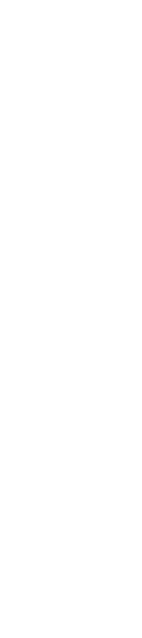




\section{FI Matias et al.}

that apomictic plants were used as a pollen donor in crosses with sexual tetraploidized plants. After hybridization, evaluations usually take approximately 10-15 years before releasing a new cultivar of tropical perennial forage (Barrios et al. 2013). During the processes, forage breeders need to apply simultaneous selection for different agronomical and nutritional traits, such as biomass production, abiotic and biotic stress tolerance, plant regrowth capacity, and forage quality, including crude protein content and animal digestibility (Hayes et al. 2013, Jank et al. 2014). However, some of these traits in $U$. decumbens have negative correlations, such as field green weight and protein content, which makes selection difficult (Matias et al. 2016).

An interesting alternative to selection for these traits with negative correlations is the use of selection indices, which allow for multi-trait selection, and thus, avoid the choice of genotypes with non-commercial standards. According to Cerón-Rojas and Crossa (2018) indices allow for the combination of economic and genetic information in multiple regression equations to predict the overall value of each individual in the population. In tropical forage breeding, indices were used to apply multivariate selection in U. humidicola (Figueiredo et al. 2012), U. decumbens (Mendonça et al. 2013), and Urochloa spp. (Matias et al. 2018).

Selection indices can be combined with multivariate analysis, such as principal component analysis (PCA), which reduces a large number of traits to a few easily visualized components (Manly and Alberto 2008). This analysis is very useful because the pattern of similarity among observations and traits is displayed by points in graphics (Abdi and Williams 2010). Genetic gains and genotype selection using PCA has been reported for several crops, such as snap beans (Oliveira et al. 2018), coffee (Zambolim et al. 2016), soybeans (Andrade et al. 2016), and sunflowers (Santos et al. 2018). In Urochloa, PCA has been used to identify traits related to drought tolerance (Cheruiyot et al. 2018), select superior genotypes for nutritional value (Moreira et al. 2018), and identify promising vigor tests for physiological quality in seed lots (Silva et al. 2018).

Selection indices and multivariate tools can be an interesting strategy associated with recurrent selection schemes in a tropical forage breeding program to identify superior genitors and hybrids of $U$. decumbens. Thus, our objectives were to: i) evaluate 1415 hybrids from the first cycle of "a recurrent selection program based on specific combining ability" with 75 full sib families of $U$. decumbens; ii) compare the efficiency of different selection indices to select superior sexual genitors for total dry matter, regrowth capacity, crude protein, digestibility, fiber, and lignin; iii) evaluate the genetic gains obtained with different selection intensities; and iv) evaluate the multivariate pattern of progenies through PCA.

\section{MATERIAL AND METHODS}

\section{Plant material and phenotyping}

An intraspecific population of $U$. decumbens was created in 2012 through crosses between 75 tetraploid sexual hybrids (pollen receptor) with the apomictic tetraploid cultivar U. decumbens. Basilisk (pollen donor) (Matias et al. 2016). This population is part of the Embrapa Beef Cattle germplasm bank located at Campo Grande (MS/ Brazil) and represents the first cycle of a recurrent selection program based on specific combining ability. The 75 sexual genitors (cycle 1) were selected individuals of 324 hybrids (cycle 0) (Mateus et al. 2015), which arose from the three tetraploidized sexual plants of $U$. decumbens as described by Simioni and Valle (2009). These 75 progenies of full siblings were evaluated in an experimental field using a complete block design with four replicates and five plants per plot, totaling 1415 hybrids.

The experiment was conducted in Campo Grande (lat $20^{\circ} 27^{\prime} \mathrm{S}$, long $54^{\circ} 37^{\prime} \mathrm{W}$, alt $530 \mathrm{~m}$ asl), in a dystroferric latosol using $1.5 \times 1.5 \mathrm{~m}$ spacing between plants. A total of seven cuts were made, five during the rainy season with an average temperature of 21-31 ${ }^{\circ} \mathrm{C}$ and precipitation of 150-200 mm per month (March 26, May 15, and December 12, 2013 , June 6 and April 2, 2014), and two during the dry season with average temperature of $16-28^{\circ} \mathrm{C}$ and precipitation of $26-80 \mathrm{~mm}$ per month (June 18 and October 16, 2013). The plants were evaluated individually for agronomic and nutritional traits as follows:

Agronomical traits: Agronomical traits included: i) total dry matter (TDM, kg ha-1) and ii) plant regrowth capacity (REG, visual score). TDM was estimated based on the green weight of the plot multiplied by the percentage of dry matter from a fresh green sub-sample of $150 \mathrm{~g}$ dried for $3 \mathrm{~d}$ at $65^{\circ} \mathrm{C}$.. REG was a visual score attained $7 \mathrm{~d}$ after cutting, which combined both the tiller density regrowth score $(1=<20 \%, 2=20 \%-40 \%, 3=40 \%-60 \%, 4=60 \%-80 \%$, and $5=>80 \%$ of tillers regrown) and speed of regrowth ( 1 = low, 2 = medium, and 3 = high), following the methodology described by Figueiredo et al. (2012). 
Nutritional traits: Traits related to nutritive value were evaluated by simulated grazing samples $1 \mathrm{~d}$ before the clipping on May 15 and December 11, 2013, (rainy season), and October 15, 2013, (dry season). Approximately $80 \mathrm{~g}$ of green forage was dried, ground, and analyzed with near infrared reflectance spectroscopy (NIRS) (Marten et al. 1989). The NIRS calibration was previously performed by comparing the results obtained in the chemical analysis versus the spectrum reading obtained from the same sample using NIRS (data not shown). This process was used to estimate the sample percentage based on percentage of TDM of: i) crude protein (CP), ii) in vitro organic matter digestibility (IVD), iii) neutral detergent fiber (NDF), and iv) lignin in sulfuric acid (LIG).

\section{Statistical analyses}

The statistical analyses were performed according to Matias et al. (2018) to evaluate the effect of progenies and predict breeding values of the 75 sexual genitors. The analysis used a complete block design and a mixed model approach (REML/BLUP) following the equation:

$$
y_{g c b}=\mu+p_{g}+q_{c}+s_{g c}+t_{b}+\varepsilon_{g c b}
$$

where $y$ is the vector for phenotypic data; $\mu$ is the overall mean (fixed); $p$ is the vector of progenies (random), with $g=\{1,2, \ldots, 75\}$ and $p \sim N\left(0, l \sigma_{g}^{2}\right) ; q$ is the vector of cuttings effect (random), with $q \sim N\left(0, l \sigma_{c}^{2}\right)$, and $c=\{1,2, \ldots, 7\}$ for agronomical traits and $c=\{1,2,3\}$ for nutritional traits; $s$ is the vector of interaction between progenies and cuttings effects (random), with $s \sim N\left(0, l \sigma_{g c}^{2}\right)$; $t$ is the vector of the block effect (random), with $b=\{1,2, \ldots, 4\}$ and $t \sim N\left(0, l \sigma_{b}^{2}\right)$; and $\varepsilon$ is the residual (random), with $\varepsilon \sim N\left(0, l \sigma_{s}^{2}\right)$. $l$ is the identity matrix. $\sigma_{g^{\prime}}^{2} \sigma_{c^{\prime}}^{2} \sigma_{g c^{\prime}}^{2}, \sigma_{b^{\prime}}^{2}$, and $\sigma_{s}^{2}$ are the variance components of each respective effect.

To evaluate the hybrid effects (1415 individuals) the analysis used an incomplete block design. The commercial cultivars $U$. brizantha Marandu, U. brizantha BRS Piatã, and $U$. decumbens Basilisk were used as checks to evaluate environmental effects. The model (1) was used with $p$ as the vector of genotypes, with $g=\{$ hybrids + checks $\}$ and $s$ as the vector of the interaction between genotype and cutting effects. The analyses were implemented using the models 136 and 138 in the software SELEGEN REML/BLUP (Resende 2016). The components of variance were tested using the likelihood ratio test (LRT) and the significance was determined using the Chi-square test with 1 degree of freedom.

An additive selection index was used to simultaneously select genitors ( 75 sexual plants) and hybrids (1415 individuals) for agronomical and nutritional traits. The index value was assigned for each individual following the equation:

$$
\mathrm{I}=\sum_{i=1}^{\mathrm{n}} G_{i} W_{i}\left(\frac{1}{\sigma_{\mathrm{g}_{1}}}\right),
$$

where, $G_{i}$ is the genotypic value of the progeny/hybrid for trait $i ; W_{i}$ is the economic weight assigned for trait $i$ (according to the Urochloa breeders experience); $\sigma_{\mathrm{g}_{1}}$ is the estimated genotypic standard deviation for trait $i$. Different economic weights were assigned for TDM, REG, CP, IVD, NDF, and LIG to define nine selection indices (Table 1). The commercial cultivars U. brizantha Marandu, U. brizantha BRS Piatã, and U. decumbens Basilisk were used to compare the performance of the indices following the relative gain equation, $\mathrm{GR}=\left[\frac{\text { (Genotype-Check) }}{\text { Check }} * 100\right]$. The realized genetic gains were obtained using $20 \%$ and $1 \%$ selection intensities and comparison with the population average and checks performance. Additionally, to verify the multivariate pattern of the 75 sexual genitors, a PCA was performed using the standardized rank of BLUPs from all agronomical and nutritional traits with the software Statistica 7.0 (Hilbe 2007).

\section{RESULTS AND DISCUSSION}

\section{Selecting sexual genitors}

All agronomical and nutritional traits had a significant effect for "progeny" and "progeny $\times$ cut" using the LRT test (p $<0.01$ ), providing a base upon which to perform selection in this population (Table 2). A significant interaction between genotypes and cuts was also identified in a previous study on this population (Matias et al. 2016), which highlighted the different performance of genotypes during the dry and wet season. This variability allowed the application of selection using only one season, as is the case when selecting to use a cover crop or selecting a genotype stable throughout the year to be used as a perennial pasture. 
Table 1. Economic weights for nine additive selection indices using total dry matter (TDM), regrowth ability (REG), crude protein (CP), in vitro digestibility of organic matter (IVD), neutral detergent fiber (NDF), and lignin (LIG)

\begin{tabular}{|c|c|c|c|c|c|c|c|c|c|}
\hline \multicolumn{10}{|c|}{ Index selection } \\
\hline Trait & 1 & 2 & 3 & 4 & 5 & 6 & 7 & 8 & 9 \\
\hline \multicolumn{10}{|l|}{ Annual } \\
\hline REG & & & & & & 0.250 & & & 0.350 \\
\hline $\mathrm{CP}$ & & & & & & 0.150 & & & \\
\hline IVD & & & & & & 0.150 & & & \\
\hline \multicolumn{10}{|c|}{ Wet season } \\
\hline TDM & 0.350 & 0.150 & 0.100 & 0.250 & & & 0.600 & & \\
\hline REG & 0.250 & 0.100 & 0.100 & 0.150 & & & 0.400 & & \\
\hline $\mathrm{CP}$ & & 0.125 & 0.100 & 0.200 & & & & & \\
\hline IVD & & 0.125 & 0.100 & 0.200 & & & & & \\
\hline TDM & 0.300 & 0.120 & 0.075 & & 0.300 & & & 0.700 & \\
\hline REG & 0.100 & 0.040 & 0.065 & & 0.100 & & & 0.300 & \\
\hline $\mathrm{CP}$ & & 0.070 & 0.065 & & 0.200 & & & & \\
\hline IVD & & 0.070 & 0.065 & & 0.200 & & & & \\
\hline NDF & & 0.025 & 0.065 & & 0.100 & & & & \\
\hline LIG & & 0.025 & 0.065 & & 0.100 & & & & \\
\hline TOTAL & 1.000 & 1.000 & 1.000 & 1.000 & 1.000 & 1.000 & 1.000 & 1.000 & 1.000 \\
\hline
\end{tabular}

When evaluating the selection performance for the full dataset (annual analysis) it was possible to observe different percentages of gains according to trait classification (agronomical or nutritional) (Table 3). The agronomical trait TDM showed greater genetic gains, ranging from $31.55 \%$ to $37.51 \%$ using a selection intensity of $20 \%$ and $1 \%$, respectively (Table 3). The lower selection gains were observed for the nutritional trait IVD, varying from $1.82 \%$ to $2.37 \%$ using the same selection intensities (Table 3). However, it is worth mentioning that even small gains in digestibility can mean significant gains in terms of animal performance under grazing.

Considering BLUPs of progenies to evaluate selection gains, the average TDM of the best $20 \%$ of progenies was $15.15 \%$ better than that of Basilisk (GRB, selection gain compared to $U$. decumbens Basilisk) and 31.55\% better than the population mean (GS, selection gains compared to the general population mean). REG had an improvement from $7 \%$ to $29 \%$ of selection gains in comparison with the GS and GRB, respectively (Table 3 ). The nutritional traits CP, NDF, and LIG did not show a significant difference between GS and GRB, indicating there was a similar nutritional value between progenies and Basilisk. When evaluating IVD, the best $20 \%$ of progenies had lower digestibility than did Basilisk, as indicated by the negative values of GRB.

This population, as described above, is cycle 1 of this recurrent selection program. Compared with cycle 0 (Mateus et al. 2015), the TDM average in this experiment increased from 1208.06 to $1926.71 \mathrm{~kg} \mathrm{ha}^{-1}$ and regrowth ability from 2.26 to 3.39 (score). Therefore, there was a genetic improvement by selecting the best $20 \%$ of the hybrids during cycle 0 (individual performance) to be the sexual genitors in cycle 1. From cycle 1 onward, the sexual genitors could be selected based on the performance of their progeny.

Comparing the genetic gains of the best $20 \%$ of progenies in relation to Basilisk using the nine selection indices, the multi-trait gains were from $0.68 \%$ to $8.69 \%$ (Table 4 - Progenies). The ranking of the progenies was used to evaluate selection coincidence among indices. It was observed that T019, T036, R134, S018, and Y021 were selected in almost all nine indices (Supplementary Table 1). These progenies represented the sexual genitors with the most stable and adapted alleles, showing high agronomical and nutritional potential to be used in a recurrent selection scheme and/or 
Table 2. Deviance (ANADEV) and likelihood ratio test (LRT) to evaluate the genetic variation among 75 full sib progenies of Urochloa decumbens

\begin{tabular}{|c|c|c|c|c|c|c|}
\hline \multicolumn{7}{|c|}{ ANADEV } \\
\hline \multirow{2}{*}{ Effect } & \multicolumn{2}{|c|}{ TDM } & \multicolumn{2}{|c|}{ REG } & \multicolumn{2}{|c|}{$\mathrm{CP}$} \\
\hline & Deviance & LRT & Deviance & LRT & Deviance & LRT \\
\hline Progeny & $132,890.64$ & $93.97^{* *}$ & 2562.27 & $31.05^{* *}$ & 7528.45 & $30.29^{* *}$ \\
\hline Progeny x Cut & $133,240.97$ & $444.30^{* *}$ & 3115.69 & $584.47^{* *}$ & 7624.87 & $126.71^{* *}$ \\
\hline Total & $132,796.67$ & & 2531.22 & & 7498.16 & \\
\hline Effect & \multicolumn{2}{|c|}{ IVD } & \multicolumn{2}{|c|}{ NDF } & \multicolumn{2}{|c|}{ LIG } \\
\hline Progeny $x$ Cut & $17,172.84$ & $81.66^{* *}$ & $12,002.26$ & $41.63^{* *}$ & -2669.02 & $46.22^{* *}$ \\
\hline Total & $17,091.18$ & & $11,960.63$ & & -2715.24 & \\
\hline
\end{tabular}

TDM: Total dry matter yield (kg ha-1); REG: Regrowth (scale of notes); CP: Crude protein (\%); IVD: In vitro digestibility of organic matter (\%); NDF: Neutral detergent fiber (\%); LIG: Lignin (\%). ** Significant $(p<0.01)$ by the $\chi^{2}$ test.

Table 3. Selection gains percentage using the BLUP (ranking) of $U$. decumbens full sib progenies regarding the general population mean (GS) and $U$. decumbens Basilisk (GRB) using the selection intensities of 20 and $1 \%$

\begin{tabular}{|c|c|c|c|c|c|c|}
\hline \multicolumn{7}{|c|}{ Selection gains - Progeny } \\
\hline Selection intensity & TDM & REG & CP & IVD & NDF & LIG \\
\hline GS $1 \%$ & 37.51 & 12.34 & 5.43 & 2.37 & 3.40 & 12.99 \\
\hline GS $20 \%$ & 31.55 & 7.32 & 4.62 & 1.82 & 2.63 & 11.47 \\
\hline GRB 1\% & 20.36 & 35.36 & 4.84 & 0.00 & 3.74 & 11.18 \\
\hline GRB 20\% & 15.15 & 29.31 & 4.03 & -0.54 & 2.97 & 9.68 \\
\hline Basilisk average & 2201.20 & 2.81 & 14.15 & 72.28 & 67.35 & 2.55 \\
\hline
\end{tabular}

TDM: Total dry matter yield ( $\mathrm{kg} \mathrm{ha}^{-1}$ ); REG: Regrowth (scale of notes); CP: Crude protein (\%); IVD: In vitro digestibility of organic matter (\%); NDF: Neutral detergent fiber (\%); LIG: Lignin (\%).

hybridization with apomictic cultivars. On the other hand, some genitors stood out only in one specific index, such as R070 and R009 for index 4 (only wet season) and genitors R006, X102, and T018 for index 5 (only dry season), reflecting the presence of adapted alleles for specific environments.

Indices 7 and 9 had higher GRB (Table 4 - Progenies) mainly because of the considerably greater weights assigned for agronomical traits during the rainy season. A similar performance was observed for $U$. humidicola using the selection index with $70 \%$ of the weight for agronomical traits during the wet season (Figueiredo et al. 2012). These indices (7 and 9) are likely overestimating the gains because of the higher genetic variability observed for agronomical traits in relation to nutritional traits in forage, as observed for Paspalum (Pereira et al. 2012, Lopes et al. 2017), Arachis (Menezes et al. 2012), Panicum maximum (Martuscello et al. 2015), U. humidicola (Figueiredo et al. 2012), and Urochloa spp. (Matias et al. 2018). In addition, the choice between indices should be made with caution, because the higher GRB of indices 7 and 9 would select progenies with better performance only during the rainy season. These genotypes can be a good option for the wet season green cover but can show lower dry season production when used as perennial pastures.

Index 6, which considers all traits during the year (annual), showed greater GRB than those that considered wet and dry season separately (Ind1, Ind2, Ind3, Ind4, Ind5, and Ind8) (Table 4 - Progenies). This index is an interesting choice to select genotypes for perennial pastures, whereas the others allowed for the selection of intermittent annual crops or cover crops only. Index 3 is another alternative for selection for different environments because of the weight assigned to account for the wet $(60 \%)$ and dry $(40 \%)$ season. Another interesting observation was that index 4 , which considered only the wet period, exhibited a greater GRB than index 5 that considered only the dry period, indicating that it was easier to observe genotypes with better performance than Basilisk in the wet season than in the dry season. Greater genetic variability during the wet season was also previously observed for the early generation of this population (Mendonça et al. 2013). 
Table 4. Index Value (VI) of U. decumbens full sib progenies and selected hybrids considering the selection of 50 top genotypes compared to U. decumbens Basilisk (GRB), U. brizantha Marandu (GRM), and U. brizantha BRS Piatã (GRP) using a $20 \%$ selection intensity

\begin{tabular}{|c|c|c|c|c|c|c|c|c|c|}
\hline \multicolumn{10}{|c|}{ Selection gains - Progenies } \\
\hline Index & Ind1 & Ind2 & Ind3 & Ind4 & Ind5 & Ind6 & Ind7 & Ind8 & Ind9 \\
\hline VI & 60.30 & 54.77 & 51.77 & 44.15 & 73.85 & 22.63 & 14.03 & 153.95 & 13.78 \\
\hline GRB (\%) & 1.73 & 1.00 & 1.26 & 1.41 & 0.69 & 2.83 & 8.69 & 0.68 & 8.60 \\
\hline \multicolumn{10}{|c|}{ Selection gains - Hybrids } \\
\hline $\mathrm{VI}$ & 9.37 & 3.99 & 0.77 & 5.21 & 3.35 & 179.41 & 12.20 & 5.63 & 102.93 \\
\hline Marandu & 9.26 & 3.93 & 0.72 & 5.10 & 3.35 & 180.74 & 12.02 & 5.61 & 104.49 \\
\hline Piatã & 8.63 & 8.23 & 4.17 & 12.07 & 3.19 & 176.77 & 11.12 & 5.36 & 101.30 \\
\hline GRB (\%) & 4.04 & 4.78 & 23.09 & 6.04 & 0.49 & 0.79 & 5.12 & 1.35 & 2.35 \\
\hline GRM (\%) & 1.13 & 1.61 & 6.70 & 2.17 & 0.08 & -0.74 & 1.46 & 0.43 & -1.50 \\
\hline GRP (\%) & 8.55 & -51.51 & -81.50 & -56.85 & 5.15 & 1.49 & 9.73 & 5.15 & 1.60 \\
\hline
\end{tabular}

Ind: Selection indices according to Table 1 for the TDM: Total dry matter yield ( $\mathrm{kg} \mathrm{ha}^{-1}$ ); REG: Regrowth (scale of notes); CP: Crude protein (\%); IVD: In vitro digestibility of organic matter (\%); NDF: Neutral detergent fiber (\%); LIG: Lignin (\%).

The Cerrado biome of Brazil (lat 3-22 $2^{\circ}$, long $39-65^{\circ} \mathrm{W}$ ) has two well-defined seasons (dry and rainy) and is classified as a tropical continental Köppen type Aw climate (Alvares et al. 2013). During the dry season, tropical forage, such as Urochloa, show a lower percentage of leaves, which are the most nutritious part of the forage, resulting in decreased CP and IVD and increased NDF and LIG (Euclides et al. 2016). These physiological and morphological differences between seasons affected the genetic variance, improving the heritability for CP and IVD, but reducing that of TDM and REG during the dry season (Matias et al. 2016). However, agronomical traits, such as TDM and REG, provided greater influence for genetic gains using indices (Table 4 - Progenies) and the reduction of genetic variability for these traits during the dry season could explain the lower gains for indices 5 and 8.

\section{Principal component analysis}

In this recurrent selection scheme with 75 sexual genitors, at least 15 to 20 genitors should be recombined to build the new breeding cycle, as recommended by Miles (2007). To improve the selection of superior progenies and better evaluate variability, another interesting breeding tool is multivariate analysis. This analysis allows graphing of the relationships among traits and the evaluation of the general performance of genotypes (Manly and Alberto 2008). In this experiment, the principal component PC1 explained the variance of TDM, REG, NDF, and LIG, whereas PC2 explained the variation of IVD and CP (Supplementary Table 2). Therefore, it is possible to name PC1 the "Agronomical Potential" and PC2 the "Nutritional Potential." According to Figure 1, PC1 explained $46.84 \%$ of the total variation, whereas PC2 explained $32.08 \%$. Because of the negative values of eigenvalues in PC1, progenies with the highest TDM, REG, NDF, and LIG are located on the left side in Figure 1, whereas progenies with greater CP and IVD (PC2) are at the bottom. A strong correlation was observed between TDM and LIG, NDF and REG, and CP with IVD. Angles between these traits were close to $0^{\circ}$ (Figure 1). In addition, these results followed the previously reported correlation values estimated for this population (Matias et al. 2016).

BRS Piatã showed the lowest CP and IVD compared with all progenies (highest point in Figure 1). Following the same principle, genitors R019, R134, T030, T019, T005, and Marandu showed greater agronomical potential, because they are at the farthest position at the left side of PC1 (Figure 1). Moreover, to begin the next breeding cycle, the $20 \%$ best sexual genitors should be recombined. One possibility is to select the sexual genitors in the 2nd and 3rd quadrants in Figure 1 (following the trait arrows, which indicates better genotype performance), i.e., T019, T005, S003, Y021, T054, X072, T030, T036, R019, B003, A018, A017, B017, S032, S018, and X006, which presented higher agronomical and nutritional potential. These sexual genitors provided the best progenies using PCA and indices (Figure 1 and Supplementary Table 1), primarily based on indices 4 and 5, which considered balanced weights between groups of traits (agronomical and nutritional).

As described above, the 75 sexual genitors came from three plants D24/2, D24/27, and D24/45, which were tetraploidized using colchicine. Plant D24/45 had a greater percentage of sexual progenies selected among the best 


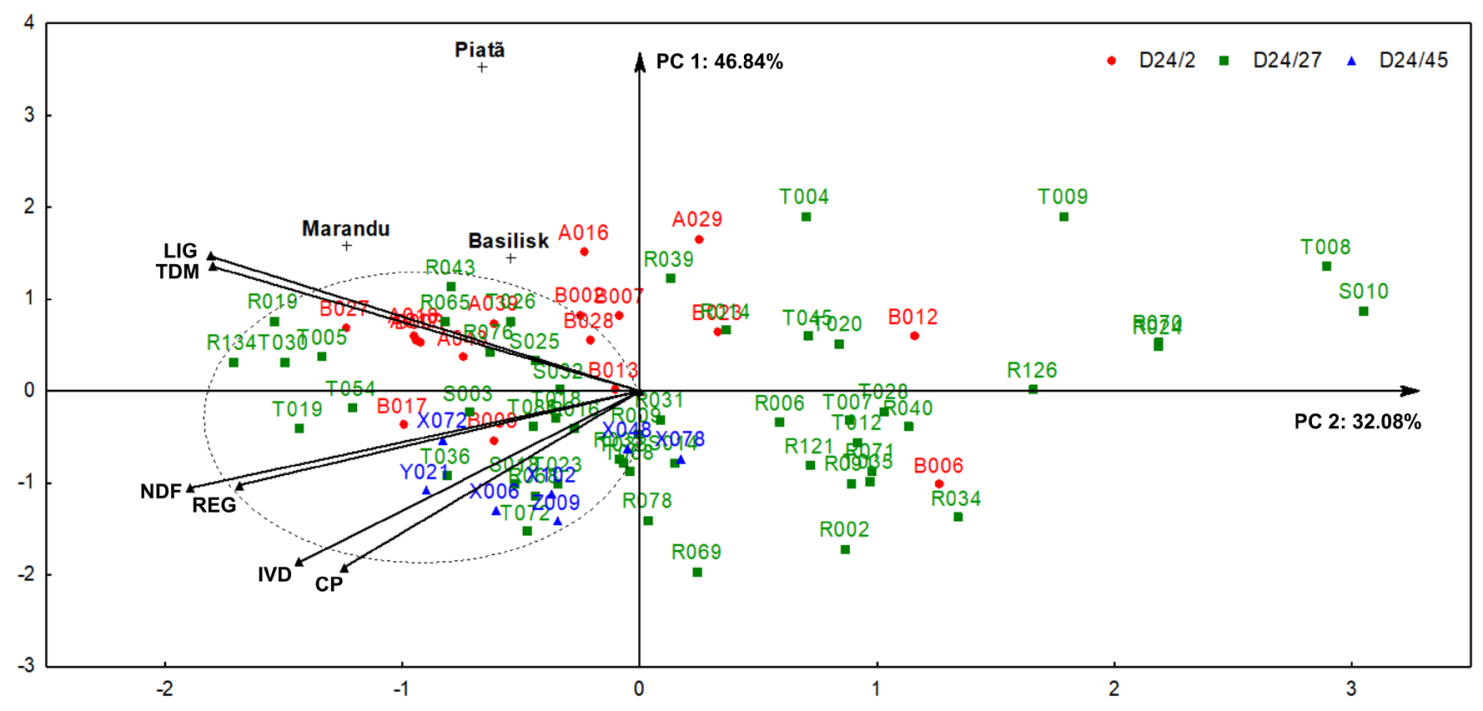

Figure 1. Biplot of principal components PC1 (46.84\%) and PC2 (32.08\%) to observe the genetic variation of $75 U$. decumbens progenies of full siblings. The 75 sexual genitors were generated by crossings with tetraploidized accessions D24/2 (red), D24/27 (green) and D24/45 (blue). TDM: Total dry matter yield (kg ha-1); REG: Regrowth (scale of notes); CP: Crude protein (\%); IVD: In vitro digestibility of organic matter (\%); NDF: Neutral detergent fiber (\%); LIG: Lignin (\%).

genitors. Plant D24/27 has progenies well distributed throughout all Biplots (Figure 1), with some genitors having great agronomical potential. The progenies from D24/2 were concentrated on the superior part of the Biplot, showing low nutritional value (Figure 1).

\section{Hybrids selection}

When evaluating intraspecific hybrids per se, Marandu showed the best REG performance of the population (GRM), and BRS Piatã showed the best NDF content (GRP) (Supplementary Table 3). However, the average of the best $20 \%$ of hybrids was greater than that of Basilisk for all traits. A similar performance was observed for the indices. The best hybrids showed positive gains compared to that of Basilisk (Table 4 - Hybrids), highlighting index 3, which had gains above $23 \%$.

The performance of Marandu was $0.74 \%$ and $1.50 \%$ superior to that of the best 50 hybrids selected using indices 6 and 9, respectively, highlighting the excellent agronomic performance of this $U$. brizantha (Table 4 - Hybrids). Similarly, $U$. brizantha BRS Piatã showed greater performance for indices 2, 3, and 4; these indices had higher weights during the wet season, indicating that this cultivar had good performance in the rainy season (Table 4 - Hybrids).

Basilisk did not appear among the top 100 selected genotypes in any of the evaluated indices, indicating that this population is commercially promising to generate better cultivars than Basilisk, which is the only commercial cultivar for this species (Jank et al. 2014) (Supplementary Table 4). However, Marandu was selected by all indices, especially indices 6 and 9, being second in rank. BRS Piatã showed good stability for all indices and was selected among the better genotypes for indices 2,3 , and 4 . Hybrids $17,1236,18,16,154$, and 151 were outstanding genotypes, which were always selected among the 10 best genotypes using the indices 1, 2, 3, 4, and 7. These hybrids showed great agronomical and nutritional potential, manly during the wet season.

Evaluating indices 5 and 8 to select better genotypes for the dry season, it was possible to select some hybrids because the check cultivar Marandu ranked $54^{\text {th }}(\operatorname{Ind} 5)$ and $76^{\text {th }}(\operatorname{Ind} 8)$. These two indices highlighted the hybrids 1229 , $1091,455,972,1075,416$, and 1119 among the top 10 selected. In addition, hybrid 1236 was classified as a potential cultivar candidate because it was selected by all indices and was among the top ranked for wet, dry, and annual analysis (Supplementary Table 4).

A good forage ideotype should have high agronomical and nutritional value to provide better animal conversion per area (Hayes et al. 2013). The ideal Urochloa cultivar should have high TDM, REG, CP, and IVD associated with low 


\section{Fl Matias et al.}

concentrations of FDN and LIG. An excellent way to combine these traits in one genotype is by performing selection through multivariate tools, such as indices and PCA. Comparing the selection indices, we verified that indices with larger assigned weights for agronomical traits provided greater selection gains, manly during the annual and wet season. Sexual genitors selected using the PCA Biplot were similar to those selected using indices, and thus, the former is an excellent option for fast and visual selection. In addition, this population had interesting hybrid candidates as new cultivars of $\mathrm{U}$. decumbens if apomictic, despite their performance as inferior to U. brizantha cultivars. U. decumbens cv. Basilisk is typically used for pastures on lower fertility soils, whereas $\mathrm{U}$. brizantha cultivars require medium fertility soils. Thus, the selection of superior $U$. decumbens genotypes could result in a large impact in the wet tropics where most perennial pastures are on poor and acidic soils.

\section{ACKNOWLEDGMENTS}

We thank the National Council for Scientific and Technological Development (CNPq), Brazilian Agricultural Research Corporation (Embrapa) for financial support. This study was financed in part by the Coordenação de Aperfeiçoamento de Pessoal de Nível Superior - Brasil (CAPES) - Finance Code 001. Supplementary Tables are available with Filipe Inácio Matias (filipematias23@gmail.com).

\section{REFERENCES}

Abdi H and Williams LJ (2010) Principal component analysis. Wiley Interdisciplinary Reviews: Computational Statistics 2: 433-459.

Alvares CA, Stape JL, Sentelhas PC, De Moraes Gonçalves JL and Sparovek G (2013) Köppen's climate classification map for Brazil. Meteorologische Zeitschrift 22: 711-728.

Andrade ACB, Silva AJ, Ferraudo AS, Unêda-Trevisoli SH and Mauro AO Di (2016) Strategies for selecting soybean genotypes using mixed models and multivariate approach. African Journal of Agricultural Research 11: 23-31.

Barrios SCL, Valle CB, Alves GF, Simeão RM and Jank L (2013) Reciprocal recurrent selection in the breeding of Brachiaria decumbens. Tropical Grasslands-Forrajes Tropicales 1: 52-54.

Cerón-Rojas JJ and Crossa J (2018) Linear selection indices in modern plant breeding. Springer, Berlin, 256p.

Cheruiyot D, Midega CAO, Van den Berg J, Pickett JA and Khan ZR (2018) Genotypic responses of brachiaria grass (Brachiaria spp.) accessions to drought stress. Journal of Agronomy 17: 136-146.

Euclides VPB, Montagner DB, Barbosa RA, Valle CB and Nantes NN (2016) Animal performance and sward characteristics of two cultivars of Brachiaria brizantha (BRS Paiaguás and BRS Piatã). Revista Brasileira de Zootecnia 45: 85-92.

Figueiredo UJ, Nunes JAR and Valle CB (2012) Estimation of genetic parameters and selection of Brachiaria humidicola progenies using a selection index. Crop Breeding and Applied Biotechnology 12: 237-244.

Hayes BJ, Cogan NOI, Pembleton LW, Goddard ME, Wang J, Spangenberg GC and Forster JW (2013) Prospects for genomic selection in forage plant species. Plant Breeding 132: 133-143.

Hilbe JM (2007) Statistica 7. The American Statistician 61: 91-94.

Jank L, Barrios SC, Valle CB, Simeão RM and Alves GF (2014) The value of improved pastures to Brazilian beef production. Crop and Pasture
Science 65: 1132-1137.

Jank L, Valle C and Resende R (2011) Breeding tropical forages. Crop Breeding and Applied Biotechnology S1: 27-34.

Lopes RR, Franke LB, Souza CHL, Bertoncelli P and Graminho LA (2017) Genetic divergence among interspecific Paspalum hybrids based on seed production traits. Ciência e Agrotecnologia 41: 390-401.

Manly BFJ and Alberto JAN (2008) Métodos estatísticos multivariados: uma introdução. Bookman Editora, Porto Alegre, 265p.

Marten GC, Shenk JS and Barton FE (Eds) (1989) Near infrared reflectance spectroscopy (NIRS): Analysis of forage quality. USDA, Agriculture handbook 643, Springfield,110p.

Martuscello JA, Braz TGS, Jank L, Cunha DNFV and Carvalho ALS (2015) Identification of ideotypes by canonical analysis in Panicum maximum. Ciência e Agrotecnologia 39: 147-153.

Mateus RG, Barrios SCL, Valle CB, Valério JR, Torres FZV, Martins LB and Amaral PNC (2015) Genetic parameters and selection of Brachiaria decumbens hybrids for agronomic traits and resistance to spittlebugs. Crop Breeding and Applied Biotechnology 15: 227-234.

Matias FI, Barrios SCL, Bearari LM, Meireles KGX, Mateus RG, Amaral PNC, Alves GF, Valle CB and Fritsche-Neto R (2018) Contribution of additive and dominance effects on agronomical and nutritional traits, and multivariate selection on Urochloa spp. hybrids. Crop Science 58: $2444-2458$.

Matias FI, Barrios SCL, Valle CB, Mateus RG, Martins LB and Moro GV (2016) Estimate of genetic parameters in Brachiaria decumbens hybrids. Crop Breeding and Applied Biotechnology 16: 115-122.

Mendonça SA, Barrios SCL, Figueiredo UJ, Alves GF and Valle CB (2013) Agronomic and nutritional evaluation of intraspecific crosses in Brachiaria decumbens. Tropical Grasslands 1: 103-105.

Menezes APM, Assis GML, Mataveli M, Silva HSF, Azevedo JMA and Mendonça MS (2012) Genetic divergence between genotypes of forage peanut in relation to agronomic and chemical traits. Revista 
Using additive indices and principal components to select sexual genitors and hybrids of Urochloa decumbens

Brasileira de Zootecnia 41: 1608-1617.

Miles JW (2007) Apomixis for cultivar development in tropical forage grasses. Crop Science 47: S-238.

Moreira EA, Souza SM, Ferreira AL, Tomich TR, Azevêdo JAG, Souza Sobrinho F, Benites FRG, Machado FS, Campos MM and Pereira LGR (2018) Nutritional diversity of Brachiaria ruziziensis clones. Ciência Rural 48: 1-8.

Oliveira TRA, Gravina GA, Oliveira GHF, Araujo LC, Araújo KC, Cruz DP, Amaral Junior AT, Vivas M and Daher RF (2018) Multivariate analysis used as a tool to select snap bean (Phaseolus vulgaris L.) genotypes. Australian Journal of Crop Science 12: 67-73.

Pereira EA, Barros T, Volkmann GK, Battisti GK, Silva JAG, Simioni C and Dall'Agnol M (2012) Variabilidade genética de caracteres forrageiros em Paspalum. Pesquisa Agropecuaria Brasileira 47: 1533-1540.

Resende MDV (2016) Software Selegen-REML/BLUP: a useful tool for plant breeding. Crop Breeding and Applied Biotechnology 16: 330-339.

RNC - Registro Nacional de Cultivares (2020) Available at < http://sistemas. agricultura.gov.br/snpc/cultivarweb/cultivares_registradas.php $>$. Accessed on February 20, 2020.

Santos ZM, De Oliveira TRA, Gravina GA, Sant'Anna CQ, Cruz DP, De
Oliveira GHF, Rocha AS, dos Santos JGC and Daher RF (2018) Yield potential of different sunflower genetic classes: A multivariate approach. Emirates Journal of Food and Agriculture 30: 1036-1041.

Silva GZ, Martins CC, Bruno RLA, Pereira FECB and Jeromini TS (2018) Multivariate analysis and vigor tests to determine the quality of Brachiaria decumbens seeds. REVISTA CIÊNCIA AGRONÔMICA 50: 291-299.

Simioni C and Valle CB (2009) Chromosome duplication in Brachiaria (A. Rich.) Stapf allows intraspecific crosses. Crop Breeding and Applied Biotechnology 9: 328-333.

Worthington M, Heffelfinger C, Bernal D, Quintero C, Zapata YP, Perez JG, De Vega J, Miles J, Dellaporta S and Tohme J (2016) A parthenogenesis gene candidate and evidence for segmental allopolyploidy in apomictic Brachiaria decumbens. Genetics 203: 1117-1132.

Worthington ML and Miles JW (2015) Reciprocal Full-sib Recurrent selection and tools for accelerating genetic gain in apomictic Brachiaria. In Budak $\mathrm{H}$ and Spangenberg $\mathrm{G}$ (eds) Molecular breeding of forage and turf. Springer, Cham, p. 19-30

Zambolim L, Souza Neto PN, Zambolim EM, Caixeta ET, Sakiyama NS and Ferrão RG (2016) Components of resistance of conilon coffee that reduce the rate of leaf rust development. Australasian Plant Pathology 45: 389-400. 